University of Nebraska - Lincoln

DigitalCommons@University of Nebraska - Lincoln

Roman L. Hruska U.S. Meat Animal Research

U.S. Department of Agriculture: Agricultural Center

Research Service, Lincoln, Nebraska

2004

\title{
Factors Regulating Lamb Longissimus Tenderness are Affected by Age at Slaughter
}

\author{
E. Veiseth \\ Agricultural University of Norway (NLH) \\ S. D. Shackelford \\ USDA-ARS \\ T. L. Wheeler \\ USDA-ARS, tommy.wheeler@ars.usda.gov \\ M. Koohmaraie \\ USDA-ARS
}

Follow this and additional works at: https://digitalcommons.unl.edu/hruskareports

Veiseth, E.; Shackelford, S. D.; Wheeler, T. L.; and Koohmaraie, M., "Factors Regulating Lamb Longissimus Tenderness are Affected by Age at Slaughter" (2004). Roman L. Hruska U.S. Meat Animal Research Center. 259.

https://digitalcommons.unl.edu/hruskareports/259

This Article is brought to you for free and open access by the U.S. Department of Agriculture: Agricultural Research Service, Lincoln, Nebraska at DigitalCommons@University of Nebraska - Lincoln. It has been accepted for inclusion in Roman L. Hruska U.S. Meat Animal Research Center by an authorized administrator of DigitalCommons@University of Nebraska - Lincoln. 


\title{
Factors regulating lamb longissimus tenderness are affected by age at slaughter ${ }^{\text {is }}$
}

\author{
E. Veiseth ${ }^{a}$, S.D. Shackelford ${ }^{\text {b }}$, T.L. Wheeler ${ }^{b}$, M. Koohmaraie ${ }^{b, *}$ \\ a Department of Chemistry and Biotechnology, Agricultural University of Norway, 1432 Aas, Norway \\ ${ }^{\mathrm{b}}$ Roman L. Hruska US Meat Animal Research Center, ARS, USDA, P.O. Box, 166, Spur 18-D, Clay Center, NE 68933-0166, USA
}

Received 24 February 2004; received in revised form 26 May 2004; accepted 26 May 2004

\begin{abstract}
The objective of this experiment was to determine age-related changes in collagen concentration, sarcomere length, calpain ( $\mu$ - and $\mathrm{m}$-) and calpastatin activities, postmortem proteolysis and Warner-Bratzler shear force (WBSF) in ovine longissimus thoracis et lumborum. Rambouillet lambs were slaughtered at 2, 4, 6, 8 and 10 months of age and samples of longissimus were collected at 0,2 and 10 days postmortem. Collagen concentration and sarcomere lengths were determined from the cores used for WBSF measurements and reflected changes in the background toughness. Longissimus collagen concentration did not change $(P>0.05)$ due to lamb age. Sarcomere lengths also showed age-related changes, increasing $(P<0.05)$ from $1.35 \mu \mathrm{m}$ at 6 months to 1.48 and $1.55 \mu \mathrm{m}$ at 8 and 10 months, respectively. The extent of calpain mediated proteolysis determines the improvement in meat tenderness with postmortem storage. The most notable change in the calpain proteolytic system was the decline $(P<0.05)$ in calpastatin activity from 4.18 to $1.91 \mathrm{U} / \mathrm{g}$ muscle between 2 and 10 months. The activity of $\mu$-calpain showed a $16 \%$ increase $(P<0.05)$ from 4 to 6 months, before it dropped again at 8 and 10 months. There was a gradual decline $(P<0.05)$ in m-calpain activity with age, and by 10 months m-calpain activity had reduced to $80 \%$ of 2 months levels. The ratio of $\mu$-calpain to calpastatin activities increased $(P<0.05)$ from 2 to 6 months (from 0.31 to 0.56$)$ with no further changes $(P>0.05)$ at 8 or 10 months. There were no age-related changes $(P>0.05)$ in desmin degradation at day 2, however, examination of day 10 samples showed increased $(P<0.05)$ degradation from 2 to 6 months. Thus, the changes observed in the ratio of $\mu$-calpain to calpastatin activities are reflected in the extent of postmortem proteolysis. Meat tenderness was measured using WBSF at 2 and 10 days postmortem. Because little proteolysis had taken place at 2 days postmortem, the decline in day 2 WBSF from 6 to 8 months could be explained by changes in sarcomere length. However, at 10 days postmortem, where WBSF was shown to decrease from 2 to 8 months, the improvement in tenderness could be explained by the amount of postmortem proteolysis. The data presented in this paper show evidence that sarcomere length is the main determinant of background toughness in ovine longissimus, and that postmortem proteolysis, resulting from $\mu$-calpain activity regulated by calpastatin, is the main determinant of ovine longissimus tenderization during aging. Thus, lamb longissimus tenderness after refrigerated storage is determined by postmortem proteolysis and its interaction with sarcomere length.
\end{abstract}

Published by Elsevier Ltd.

Keywords: Calpains; Calpastatin; Collagen; Proteolysis; Sarcomere; WBSF

\footnotetext{
Names are necessary to report factually on available data; however, the USDA neither guarantees nor warrants the standard of the product, and the use of the name by USDA implies no approval of the product to the exclusion of others that may also be suitable.

${ }^{*}$ Corresponding author. Tel.: +1-402-762-4221; fax: +1-402-7624149.

E-mail address: koohmaraie@email.marc.usda.gov (M. Koohmaraie).
}

\section{Introduction}

Variation in tenderness is a major concern for the US meat industry, and effort has been put into understanding the causes for this variation. In a study to determine the sources of variation in meat tenderness, Wheeler and Koohmaraie (1994) concluded that sarcomere shortening during rigor development was the cause of toughening of lamb longissimus thoracis et lumborum from 0 to $24 \mathrm{~h}$ postmortem, referred to as the tough- 
ening phase. Further, Koohmaraie, Doumit, and Wheeler (1996) showed that if longissimus is prevented from shortening during the period of rigor development, shear force values do not increase. While the toughening phase is similar in all carcasses, the tenderization process is highly variable. Evidence has shown that the calpain proteolytic system is responsible for postmortem tenderization during cooler storage (for reviews, see Goll, Taylor, Christiansen, \& Thompson, 1991; Koohmaraie, 1994, 1996); specifically, $\mu$-calpain degrades key myofibrillar and associated proteins, leading to weakening of myofibrils and, thus, tenderization. The tenderness variation in longissimus after postmortem storage is caused by variation in the rate and extent of postmortem proteolysis by the calpain system.

Several studies have investigated the effect of animal age on meat tenderness, and produced contradicting conclusions. While some groups reported a decrease in meat tenderness with increasing animal age (Hiner \& Hankins, 1950; Reagan, Carpenter, \& Smith, 1976), others have found an increase (Duckett, Snowder, \& Cockett, 2000) or no effect (Dikeman et al., 1986; Weller, Galgan, \& Jacobson, 1962). Further, it has been shown that activity levels of the calpain proteolytic system, particularly calpastatin, change with animal age (Northcutt, Pringle, Dickens, Buhr, \& Young, 1998; Ou, Meyer, \& Forsberg, 1991; Whipple \& Koohmaraie, 1992). The objective of this paper was to examine the effect of age on the calpain proteolytic system, postmortem proteolysis and meat tenderness of ovine longissimus.

\section{Materials and methods}

\subsection{Animals}

The Roman L. Hruska US Meat Animal Research Center (MARC) Animal Care and Use Committee approved the use of animals for this study. Fifty-nine Rambouillet lambs were slaughtered at 2, 4, 6, 8 and 10 months of age $(n=12$ per age group, except at 10 months where $n=11$ ). Within $20 \mathrm{~min}$ of exsanguination, longissimus thoracis et lumborum from one side of the carcass was removed for analysis of calpain and calpastatin activities, diced muscle was also snap frozen in liquid nitrogen for immunological analysis. The carcasses were stored at $1{ }^{\circ} \mathrm{C}$ until $48 \mathrm{~h}$ postmortem, when the whole longissimus from the other side of the carcass was dissected out, trimmed of subcutaneous fat and weighed. Starting at the posterior end of the longissimus, samples were taken in the following order: day $2 \mathrm{im}$ munological analyses (snap frozen), day 2 WarnerBratzler Shear Force (WBSF), day 10 WBSF and day 10 immunological analyses (snap frozen). The portions for day 10 analyses were vacuum packed as one portion and stored at $1{ }^{\circ} \mathrm{C}$ until 10 days postmortem. Due to limited sample size, WBSF analyses at 2 days postmortem were not performed for 2-month old lambs.

\subsection{Calpains and calpastatin}

Longissimus used for analysis of the proteolytic activities of $\mu$-calpain and m-calpain and the inhibitory activity of calpastatin was trimmed of visible fat and connective tissue and finely diced. The muscle extracts were prepared by homogenizing $50 \mathrm{~g}$ of muscle in 3 volumes of prerigor extraction buffer $(50 \mathrm{mM}$ Tris base, $10 \mathrm{mM}$ EDTA, 0.05\% 2-mercaptoethanol [MCE], $2 \mathrm{mM}$ phenylmethylsulfonyl fluoride [PMSF], $100 \mathrm{mg} / \mathrm{L}$ ovomucoid, $16 \mathrm{mg} / \mathrm{L}$ leupeptin, adjusted with $\mathrm{HCl}$ to $\mathrm{pH}$ 8.3). Homogenization was performed using a Waring blender (Dynamics Co. of America, New Hartford, CT) $3 \times 30 \mathrm{~s}$ on high speed interspersed with $30 \mathrm{~s}$ cooling periods. The homogenate was centrifuged at $16,000 g_{\max }$ for $2 \mathrm{~h}$ and the supernatant was dialyzed against dialysis buffer ( $40 \mathrm{mM}$ Tris base, $5 \mathrm{mM}$ EDTA, 0.05\% MCE, pH $7.35)$ overnight. The following day, samples were clarified by centrifugation at $28,000 g_{\max }$ for $1 \mathrm{~h}$ and filtered over glass wool, before loading by gravity onto $212-\mathrm{mL}$ DEAE-Sephacel columns equilibrated with elution buffer (40 mM Tris base, $0.5 \mathrm{mM}$ EDTA, $0.05 \% \mathrm{MCE}$, $\mathrm{pH}$ 7.35). Columns were washed with elution buffer until the $\mathrm{A}_{278}$ of the outflow was less than 0.1. Bound proteins were eluted with a gradient from 25 to $500 \mathrm{mM} \mathrm{NaCl}$ (375 mL of elution buffer containing 25 and $500 \mathrm{mM}$ $\mathrm{NaCl} ; 40 \mathrm{~mL} / \mathrm{h}$ ), and 140 fractions of $5 \mathrm{~mL}$ were collected. The proteolytic activities of $\mu$-calpain and $\mathrm{m}$-calpain and the inhibitory activity of calpastatin in these fractions were determined using a standard casein assay as described by Koohmaraie (1990).

\subsection{Warner-Bratzler shear force}

The portions of longissimus assigned for WBSF determination were cut into $2.54 \mathrm{~cm}$ thick chops and cooked on a belt grill (Model TBG-60 Magigrill, MagiKitch'n Inc., Quakertown, PA). Belt grill settings necessary to achieve a final temperature of $71{ }^{\circ} \mathrm{C}$ for 2.54 $\mathrm{cm}$ thick lamb chops were determined: top and bottom heat $=163{ }^{\circ} \mathrm{C}$, preheat $=149{ }^{\circ} \mathrm{C}$, height (gap between platens $)=2.16 \mathrm{~cm}$, cook time $=5.3 \mathrm{~min}$. Warner-Bratzler shear force was determined as described by Wheeler, Shackelford, and Koohmaraie (1998).

\subsection{Sarcomere length}

Sarcomere lengths were determined on the cooked cores, after determination of WBSF, as described by Wheeler, Shackelford, and Koohmaraie (2002) for cooked samples. One cube of tissue was removed from each core and fixed as described by Koolmees, Korteknie, 
and Smulders (1986). Six fibers were pulled out of each cube (total of 36 fibers per observation), and sarcomere lengths were determined by helium neon laser diffraction (Model 05-LHR-021, Melles Griot, Carlsbad, CA) according to Cross, West, and Dutson (1981).

\subsection{Collagen concentration}

Collagen concentration was estimated from cores (Wheeler et al., 2002), after determination of WBSF, for hydroxyproline quantification according to Avery, Sims, Warkup, and Bailey (1996) with modifications by Wheeler et al. (2002). Data were expressed as milligrams of collagen per gram of cooked muscle.

\subsection{Immunoblotting}

Protein extraction, electrophoresis, Western blotting and quantification of desmin were conducted as described by Wheeler et al. (2002). At-death reference samples for each animal were used to calculate percentage desmin degradation at 2 and 10 days postmortem.

\subsection{Statistical analysis}

Data were analyzed by one-way analysis of variance using the GLM procedures of SAS (SAS Inst. Inc., Cary, NC), where age at slaughter was treated as a class (not continuous) variable with five levels $(2,4,6,8$ and 10 months). When the effect of age at slaughter was significant, means were separated using the PDIFF procedure, a pair-wise $t$-test.

\section{Results and discussion}

Not surprisingly, hot carcass weight (HCW) and longissimus weight increased $(P<0.05)$ with age (Table 1$)$. Both these weights approximately quadrupled between 2 and 10 months. The concurrent changes in HCW and longissimus weight were reflected in a correlation of 0.96 between these two traits (data not shown).

Several studies have explored the relationship between meat tenderness and animal age, and reports exist which show no relationship (Dikeman et al., 1986; Weller et al., 1962), and both positive (Duckett et al., 2000) and negative (Hiner \& Hankins, 1950; Reagan et al., 1976) relationships. As shown in Table 1, there was no difference $(P>0.05)$ in day $2 \mathrm{WBSF}$ between 4- and 6-month or between 8- and 10-month old lambs. However, a decline $(P<0.05)$ in day 2 WBSF was detected between 6 and 8 months. Day 10 WBSF showed a gradual decline $(P<0.05)$ from 2 to 6 months, and then a large decrease $(P<0.05)$ between 6 and 8 months. Overall, the day $10 \mathrm{WBSF}$ values more than halved

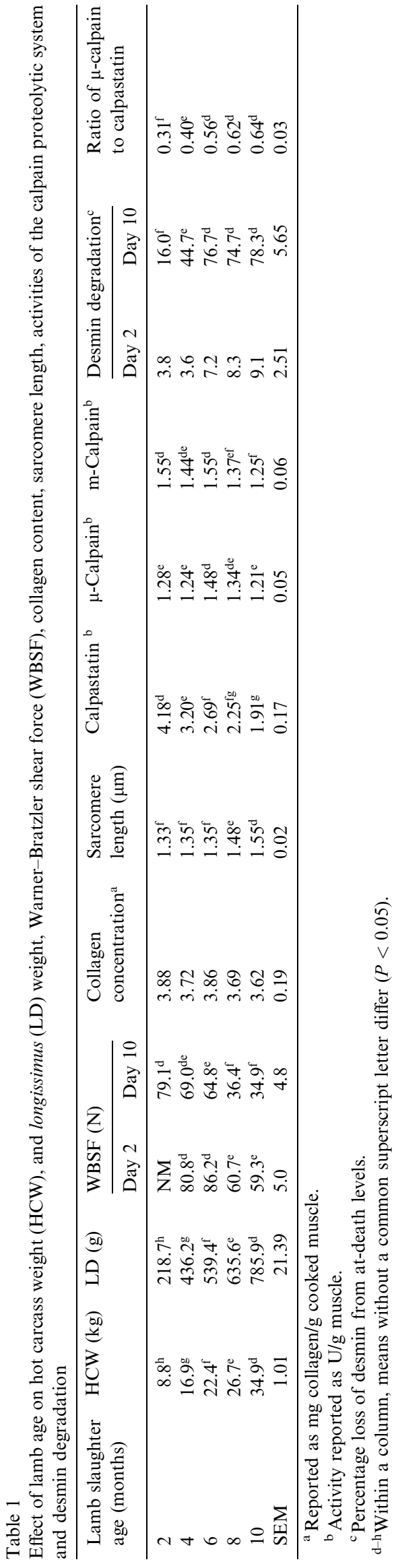


between 2 and 10 months. Similar results have been reported from lambs ranging from 100 to 246 days of age (Duckett et al., 2000). To determine the source of age-related variation in WBSF, traits known to influence meat tenderness were measured.

For the purposes of this study, we have differentiated between tenderness at the completion of rigor (background toughness) and improvements in tenderness with postmortem storage (tenderization). Background toughness is attributed to collagen concentration and sarcomere length. While there are no changes in collagen concentration during postmortem storage (Koohmaraie, Seideman, Schollmeyer, Dutson, \& Crouse, 1987), sarcomeres shorten during rigor development (Wheeler \& Koohmaraie, 1994) and may (Gothard, Mullens, Boulware, \& Hansard, 1966; Stromer, Goll, \& Roth, 1967; Wheeler \& Koohmaraie, 1994) or may not (Wheeler \& Koohmaraie, 1999), then lengthen slightly with extended storage. Tenderization is primarily dependent on postmortem proteolysis mediated by the calpain proteolytic system (Koohmaraie, 1994, 1996). Thus, ultimate tenderness after postmortem storage of meat is determined by both background toughness and tenderization. Wheeler, Shackelford, and Koohmaraie (2000) examined the variation in tenderness at 1 day postmortem in five different pork muscles, and found that the relative contribution of collagen content, sarcomere length and postmortem proteolysis to meat tenderness variation was muscle-specific. Because Wheeler et al. (2002) showed that analyses of biochemical traits, including collagen content and sarcomere length, on the cooked cores used for WBSF determination could explain more of the variation of tenderness measurements than analyses performed on raw samples, we chose to perform collagen content and sarcomere length analysis on the cooked cores used for day 10 WBSF determinations.

As shown in Table 1, collagen concentration per gram cooked muscle was not affected $(P>0.05)$ by lamb age.

No change in sarcomere length occurred during the first 6 months, but sarcomeres were less contracted $(P<0.05)$ at 8 and again at 10 months (Table 1$)$. Smith, Dutson, Hostetler, and Carpenter (1976) showed that lamb carcasses with increased quantities of fat chilled more slowly and had less shortening of sarcomeres. Thus, increasing amounts of subcutaneous fat and increasing longissimus size with increasing age, leading to slower temperature decline, is a possible explanation for the reduced shortening of sarcomeres at 8 and 10 months in this study. Previously, it has been shown that there is a strong positive relationship between sarcomere length and meat tenderness when the sarcomeres are shorter than $2.0 \mu \mathrm{m}$ (Bouton, Harris, Shorthose, \& Baxter, 1973; Herring, Cassens, Suess, Brungardt, \& Briskey, 1967; Wheeler et al., 2000). Since all sarcomere lengths in this study were shorter than $2.0 \mu \mathrm{m}$, it is likely that the changes in sarcomere length would affect the background toughness of longissimus. However, the relative significance of sarcomere length on ultimate tenderness is dependent upon the extent of tenderization resulting from the third factor, proteolysis (Wheeler et al., 2000).

Several groups have examined the effect of animal age on the calpain proteolytic system. Typically, studies indicate that calpain and calpastatin activities decline with increasing animal age (Northcutt et al., 1998; Ou \& Forsberg, 1991; Ou et al., 1991; Shackelford, Wheeler, \& Koohmaraie, 1995). As shown in Table 1, there was a steady decline $(P<0.05)$ in calpastatin activity with increasing age in this study, and at 10 months calpastatin activity had dropped to less than one-half of the activity measured at 2 months. Duckett et al. (2000) also found a comparable decline in calpastatin activity between 19- and 246-days old lambs. The changes detected in $\mu$-calpain and m-calpain activities were not as dramatic (Table 1). There was a $16 \%$ increase $(P<0.05)$ in $\mu$-calpain activity between 2 and 6 months, however, in 8 -month lambs, $\mu$-calpain activity had returned to the levels found at 2 months. No changes $(P>0.05)$ were detected in m-calpain activity during the first 6 months, but a decrease $(P<0.05)$ was detected at 8 and 10 months. There was approximately $20 \%$ less m-calpain activity detected at 10 months compared to activities measured during the first 6 months.

The impact of changes in calpain and calpastatin activities upon proteolysis was examined by quantifying loss of native desmin during postmortem storage of longissimus. Previously, we have shown that it was possible to detect loss of desmin as early as $9 \mathrm{~h}$ postmortem and that $31 \%$ of desmin was lost by $24 \mathrm{~h}$ postmortem in ovine longissimus (Veiseth, Shackelford, Wheeler, \& Koohmaraie, 2004). However, in this study, relatively little desmin proteolysis $(<9.1 \%)$ had occurred at 2 days postmortem, and the extent of proteolysis at day 2 was not influenced $(P>0.05)$ by animal age (Table 1). At 10 days postmortem, age related differences became apparent. Desmin degradation detected at 10 days postmortem increased $(P<0.05)$ from 2 to 6 months, but no further increases $(P>0.05)$ in desmin degradation were detected from 6 to 10 months. The result that younger lambs had less desmin proteolysis in the longissimus than older lambs agrees with Whipple and Koohmaraie (1992), who found that 8-week old lambs had less postmortem proteolysis than 26 -week old lambs.

Because m-calpain is not active under normal postmortem conditions (Koohmaraie et al., 1987; Veiseth, Shackelford, Wheeler, \& Koohmaraie, 2001), the reduction detected in measurable m-calpain activity with increasing lamb age in this study is not expected to have an effect on postmortem proteolysis. Changes in postmortem proteolysis are likely to be due to changes in the 
relative activities of $\mu$-calpain and calpastatin. Previously, elevated calpastatin activities have been shown to be responsible for reduced $\mu$-calpain to calpastatin ratios, and have resulted in a reduced rate and extent of postmortem proteolysis. Examples of this include in vitro models, such as myofibril incubations (Geesink \& Koohmaraie, 1999a), and in vivo models, such as callipyge lambs (Geesink \& Koohmaraie, 1999b; Koohmaraie, Shackelford, Wheeler, Lonergan, \& Doumit, 1995) and $\beta$-adrenergic agonist administration (Koohmaraie, Shackelford, Muggli-Cockett, \& Stone, 1991; Kretchmar, Hathaway, Epley, \& Dayton, 1990). Therefore, the reduced calpastatin activity detected from 2 to 6 months in this study may be responsible for the significant increases in desmin degradation detected at 10 days postmortem over the same period. Although calpastatin activity showed an additional decline from 6 to 10 months, no further increases in desmin degradation were detected from 6 to 10 months. The lack of further improvements in desmin degradation during this period can be explained, however, by considering the changes in calpastatin and $\mu$-calpain activities simultaneously. While calpastatin showed a gradual decline throughout the increasing age groups, $\mu$-calpain showed an increase at 6 months before it declined again at 10 months. $\mathrm{Cu}-$ mulatively, these changes increased $(P<0.05)$ the ratio of $\mu$-calpain to calpastatin activities from 2 to 6 months, but no further changes were detected up to 10 months (Table 1). Thus, the increase in the ratio of $\mu$-calpain to calpastatin activities from 2 to 6 months coincided with increased postmortem proteolysis. Additionally, when the ratio of $\mu$-calpain to calpastatin activities did not change $(P>0.05)$ from 6 to 10 months, the extent of proteolysis did not change either.

By examining collagen concentration, sarcomere length and proteolysis, it is possible to assess the impact of these traits on meat tenderness at different ages. In this study, collagen concentration did not contribute to differences in longissimus WBSF among lamb ages. Thus, the age-related changes in WBSF at 2 and 10 days postmortem must be related to changes in either sarcomere length, postmortem proteolysis, or both. Since the level of desmin degradation at day 2 did not change with age, WBSF differences at 2 days postmortem are more likely to be related to changes in background toughness. Indeed, the decrease in day $2 \mathrm{WBSF}$ at 8 and 10 months coincided with a reduced shortening of sarcomeres at the same time (Table 1). However, the gradual decrease in WBSF at 10 days postmortem was a result of increasing postmortem proteolysis, which was a consequence of decreasing calpastatin activity and an increasing $\mu$-calpain to calpastatin ratio. Importantly, even at 10 days postmortem the effect of increasing sarcomere length on WBSF was detectable, emphasizing the importance of sarcomere length on the background toughness of longissimus. The results in this study demonstrated that increasing lamb age had a positive effect on desmin proteolysis and sarcomere length and a neutral effect on collagen concentration. Cumulatively, these changes result in improvement of ultimate longissimus tenderness as slaughter age of lambs increases from 2 to 10 months.

\section{Acknowledgements}

The authors gratefully acknowledge the technical assistance of Patty Beska, Peg Ekeren, Sue Hauver, Kathy Mihm and Pat Tammen and the secretarial assistance of Marilyn Bierman and Carol Grummert.

\section{References}

Avery, N. C., Sims, T. J., Warkup, C., \& Bailey, A. J. (1996). Collagen cross-linking in porcine $M$. longissimus lumborum: Absence of a relationship with variation in texture at pork weight. Meat Science, 42, 355-369.

Bouton, P. E., Harris, P. V., Shorthose, W. R., \& Baxter, R. I. (1973). A comparison of the effects of aging, conditioning and skeletal restraint on the tenderness of mutton. Journal of Food Science, 38, 932-937.

Cross, H. R., West, R. L., \& Dutson, T. R. (1981). Comparison of methods for measuring sarcomere length in beef semitendinosus muscle. Meat Science, 5, 261-266.

Dikeman, M. E., Reddy, G. B., Arthaud, V. H., Tuma, H. J., Koch, R. M., Mandigo, R. W., \& Axe, J. B. (1986). Longissimus muscle quality, palatability and connective tissue histological characteristics of bulls and steers fed different energy levels and slaughtered at four ages. Journal of Animal Science, 63, 92-101.

Duckett, S. K., Snowder, G. D., \& Cockett, N. E. (2000). Effect of the callipyge gene on muscle growth, calpastatin activity, and tenderness of three muscles across the growth curve. Journal of Animal Science, 78, 2836-2841.

Geesink, G. H., \& Koohmaraie, M. (1999a). Effect of calpastatin on degradation of myofibrillar proteins by $\mu$-calpain under postmortem conditions. Journal of Animal Science, 77, 2685-2692.

Geesink, G. H., \& Koohmaraie, M. (1999b). Postmortem proteolysis and calpain/calpastatin activity in callipyge and normal lamb biceps femoris during extended postmortem storage. Journal of Animal Science, 77, 1490-1501.

Goll, D. E., Taylor, R. G., Christiansen, J. A., \& Thompson, V. F. (1991). Role of proteinases and protein turnover in muscle growth and meat quality. Proceedings of the Reciprocal Meat Conference, $44,25-33$.

Gothard, R. H., Mullens, A. M., Boulware, R. F., \& Hansard, S. L. (1966). Histological studies of post-mortem changes in sarcomere length as related to bovine muscle tenderness. Journal of Food Science, 31,825 .

Herring, H. K., Cassens, R. G., Suess, G. G., Brungardt, V. H., \& Briskey, E. J. (1967). Tenderness and associated characteristics of stretched and contracted bovine muscles. Journal of Food Science, $32,317-323$.

Hiner, R. L., \& Hankins, O. G. (1950). The tenderness of beef in relation to different muscles and age in the animal. Journal of Animal Science, 9, 347-353.

Koohmaraie, M. (1990). Quantification of $\mathrm{Ca}^{2+}$-dependent protease activities by hydrophobic and ion-exchange chromatography. Journal of Animal Science, 68, 659-665.

Koohmaraie, M. (1994). Muscle proteinases and meat aging. Meat Science, 36, 93-104. 
Koohmaraie, M. (1996). Biochemical factors regulating the toughening and tenderization processes of meat. Meat Science, 43, S193-S201.

Koohmaraie, M., Doumit, M. E., \& Wheeler, T. L. (1996). Meat toughening does not occur when rigor shortening is prevented. Journal of Animal Science, 74, 2935-2942.

Koohmaraie, M., Seideman, S. C., Schollmeyer, J. E., Dutson, T. R., \& Crouse, J. D. (1987). Effect of post-mortem storage on $\mathrm{Ca}^{2+}$. dependent proteases, their inhibitor and myofibril fragmentation. Meat Science, 19, 187-196.

Koohmaraie, M., Shackelford, S. D., Muggli-Cockett, N. E., \& Stone, R. T. (1991). Effect of the $\beta$-adrenergic agonist $\mathrm{L}_{644,969}$ on muscle growth, endogenous proteinase activities, and postmortem proteolysis in wether lambs. Journal of Animal Science, 69, 48234835.

Koohmaraie, M., Shackelford, S. D., Wheeler, T. L., Lonergan, S. M., \& Doumit, M. E. (1995). A muscle hypertrophy condition in lamb (callipyge): Characterization of effects on muscle growth and meat quality traits. Journal of Animal Science, 73, 3596-3607.

Koolmees, P. A., Korteknie, F., \& Smulders, F. J. M. (1986). Accuracy and utility of sarcomere length assessment by laser diffraction. Food Microstructure, 5, 71-76.

Kretchmar, D. H., Hathaway, M. R., Epley, R. J., \& Dayton, W. R. (1990). Alterations in postmortem degradation of myofibrillar proteins in muscle of lambs fed a $\beta$-adrenergic agonist. Journal of Animal Science, 68, 1760-1772.

Northcutt, J. K., Pringle, T. D., Dickens, J. A., Buhr, R. J., \& Young, L. L. (1998). Effects of age and tissue type on the calpain proteolytic system in turkey skeletal muscle. Poultry Science, 77, 367-372.

Ou, B. R., \& Forsberg, N. E. (1991). Determination of skeletal muscle calpain and calpastatin activities during maturation. American Journal of Physiology, 261, E677-E683.

Ou, B. R., Meyer, H. H., \& Forsberg, N. E. (1991). Effects of age and castration on activities of calpains and calpastatin in sheep skeletal muscle. Journal of Animal Science, 69, 1919-1924.

Reagan, J. O., Carpenter, Z. L., \& Smith, G. C. (1976). Age-related traits affecting the tenderness of the bovine longissimus muscle. Journal of Animal Science, 43, 1198-1205.

Shackelford, S. D., Wheeler, T. L., \& Koohmaraie, M. (1995). The effects of in utero exposure of lambs to a $\beta$-adrenergic agonist on prenatal and postnatal muscle growth, carcass cutability, and meat tenderness. Journal of Animal Science, 73, 2986-2993.

Smith, G. C., Dutson, T. R., Hostetler, R. L., \& Carpenter, Z. L. (1976). Fatness, rate of chilling and tenderness of lamb. Journal of Food Science, 41, 748-756.

Stromer, M. H., Goll, D. E., \& Roth, L. E. (1967). Morphology of rigor-shortened bovine muscle and the effect of trypsin on pre- and postrigor myofibrils. Journal of Cell Biology, 34, 431.

Veiseth, E., Shackelford, S. D., Wheeler, T. L., \& Koohmaraie, M. (2001). Effect of postmortem storage on $\mu$-calpain and m-calpain in ovine skeletal muscle. Journal of Animal Science, 79, 1502-1508.

Veiseth, E., Shackelford, S. D., Wheeler, T. L., \& Koohmaraie, M. (2004). Indicators of tenderization are detectable by $12 \mathrm{~h}$ postmortem in ovine longissimus. Journal of Animal Science, 82, $1428-1436$.

Weller, M., Galgan, M. W., \& Jacobson, M. (1962). Flavor and tenderness of lamb as influenced by age. Journal of Animal Science, 21, 927-929.

Wheeler, T. L., \& Koohmaraie, M. (1994). Prerigor and postrigor changes in tenderness of ovine longissimus muscle. Journal of Animal Science, 72, 1232-1238.

Wheeler, T. L., \& Koohmaraie, M. (1999). The extent of proteolysis is independent of sarcomere length in lamb longissimus and psoas major. Journal of Animal Science, 77, 2444-2451.

Wheeler, T. L., Shackelford, S. D., \& Koohmaraie, M. (1998). Cooking and palatability traits of beef longissimus steaks cooked with a belt grill or an open hearth electric broiler. Journal of Animal Science, 76, 2805-2810.

Wheeler, T. L., Shackelford, S. D., \& Koohmaraie, M. (2002). Technical note: Sampling methodology for relating sarcomere length, collagen concentration, and the extent of postmortem proteolysis to beef and pork longissimus tenderness. Journal of Animal Science, 80, 982-987.

Wheeler, T. L., Shackelford, S. D., \& Koohmaraie, M. (2000). Variation in proteolysis, sarcomere length, collagen content, and tenderness among major pork muscles. Journal of Animal Science, 78, 958-965.

Whipple, G., \& Koohmaraie, M. (1992). Effects of lamb age, muscle type, and 24-h activity of endogenous proteinases on postmortem proteolysis. Journal of Animal Science, 70, 798-804. 